\author{
21st Annual Meeting of the Society for Computers in Psychology \\ San Francisco, California \\ November 21, 1991
}

The 21 st Annual Meeting of the Society for Computers in Psychology will be held at the Hyatt Regency Hotel at Embarcadero Center in San Francisco on November 21, 1991, the day before the annual meeting of the Psychonomic Society. The meeting will include presentations, discussions, tutorials, and times for software and hardware demonstrations. All areas of psychology are featured, including research, education, clinical practice, and industrial applications.

For further information regarding the conference, contact William L. Palya, Department of Psychology, Jacksonville State University, Jacksonville, AL 36265 (BITNET address FWLP@JSUMUS, phone (205) 7825641, FAX (205) 782-5680).

\title{
32nd Annual Meeting of the Psychonomic Society San Francisco, California November 22-24, 1991
}

The 32nd Annual Meeting of the Psychonomic Society will be held in San Francisco, November 22-24, 1991. The meetings will begin Friday morning and continue until Sunday at noon. The headquarters hotel will be the Hyatt Regency San Francisco at Embarcadero Center.

The call for papers was mailed to members and associates in April, with a June 21 deadline for submissions.

The program and hotel reservation cards will be mailed to members and associates in September. A copy of the program will be published in the November issue of the Bulletin of the Psychonomic Society.

For further information, please contact the secretary-treasurer of the Society: Cynthia H. Null, P.O. Box 7104, San Jose, California 95150-7104 (telephone: 415-604-1260).

\section{Conference on Computing for the Social Sciences University of Michigan, Ann Arbor May 4-7, 1992}

The 1992 conference on Computing for the Social Sciences-CSS92-will be held May 4-7, 1992, at the University of Michigan in Ann Arbor. A call for papers will be announced in early September with a deadline of December 1. Conference registration material will be available in January.

If you would like to be added to our mailing list, please send your name and address in any one of the following ways: BITNET, userCS92@umichum; Internet, CSS92@um.cc.umich.edu; FAX, 313-764-1557; U.S. Mail, CSS92, University of Michigan, Department of Conferences and Seminars, 541 Thompson StreetRoom 112, Ann Arbor, MI 48109-1360. 